\title{
Educar en las primeras infancias: una experiencia de formación docente en nutrición y alimentación saludable
}

\author{
Ravelli, Sandra; ${ }^{1}$ Manuale, Marcela ${ }^{1}$
}

Recibido: 22/09/2016

Aprobado: 26/10/2016

\section{Resumen}

El presente trabajo analiza una experiencia de formación docente centrada en la Educación Alimentaria Nutricional, que permitió fortalecer vínculos entre la universidad y otros niveles del sistema educativo, promoviendo intervenciones en la intersección entre educación, salud y primeras infancias. Desde la propuesta del Programa Nacional de Formación Permanente, del Ministerio de Educación de la Nación, se propuso desde la Facultad de Bioquímica y Ciencias Biológicas (FBCB) de la Universidad Nacional del Litoral (UNL) un curso de capacitación denominado "Salud, nutrición y educación infantil: construyendo estrategias en el nivel inicial“, donde participaron docentes y directivos de nivel inicial, docentes del primer ciclo de educación primaria, alumnos avanzados de formación docente, especialmente del Profesorado de Educación Física y alumnos avanzados de la carrera de Licenciatura en Nutrición (LN) y de Terapia Ocupacional FBCB-UNL. El desarrollo de esta experiencia de formación pedagógica posibilitó el diseño y desarrollo de propuestas educativas contextualizadas, transfiriendo los ejes vinculados a la salud y nutrición trabajados a las prácticas de enseñanza en los niveles involucrados.

Palabras clave: Formación docente, Educación Alimentaria Nutricional, Programa Nacional de Formación Permanente, Vínculos Universidad-Institutos de Formación docente-Establecimientos de nivel inicial, Educación para las primeras infancias.

\footnotetext{
${ }^{1}$ Universidad Nacional del Litoral. Facultad de Bioquímica y Ciencias Biológicas. Paraje El pozo S/N - Santa Fe - Argentina - Código Postal 3000 - Teléfono 0342-4575215 - correo: manuale@fbcb.unl.edu.ar
} 


\section{Summary}

This paper analyzes an experience of teaching training focused on food nutrition education, which strengthened links between the University and other levels of the education system, promoting interventions at the intersection of education, health and early childhood. Basing on the proposal of the National Program of Continuing Education, launched by the National Ministry of Education, a training course called "Health, Nutrition and Children Education: building strategies at the initial level" was proposed from the Faculty of Biochemistry and Sciences biological (FBCB) of the National University of the Littoral (UNL). It was attended by teachers and directors of initial level, teachers of the first cycle of primary education, advanced students of teacher training, especially the Faculty of Physical Education and advanced students of degree in Nutrition (LN) and FBCB-UNL Occupational Therapy. The development of this experience of training pedagogical enabled the design and development of contextualized educational proposals, transferring those worked axes linked to health and nutrition toward the teaching practices there involved.

Key words: Training teaching, food and nutrition education, National Program for Continuing Training, University- Teacher Training Institutes - Entry-Level Establishments Linkage, Education for Early childhoods. 